\title{
Study of Electrical Systems in Engineering Faculty Udayana University Bukit Jimbaran
}

\author{
I G N Janardana ${ }^{1}$, W ArtaWijaya ${ }^{2}$ \\ Electrical Engineering Department ${ }^{1,2}$ \\ Faculty of Engineering Udayana University \\ Badung, Indonesian \\ janardana@unud.ac.id
}

\begin{abstract}
Electrical systems that serve the Dean of electricity load, the electricity load of the Departement of Architecture, Departement of Mechanical Engineering, Departement of Electrical Engineering, Departement of Information Technology, external lighting facilities supplied by transformers with a capacity of 200 KVA. Lately the quality electrical system has begun to decline with frequent interruptions such as the breakdown of electricity to the load, unbalanced load, THD current exceeds the standard, the fuse on the incoming to the parent panel and the fuse on the main panel is often burned, the grounding system resistance value exceeds the standard equipment value, cable temperature exceeds the standard, even voltage rises to 500 volts. The purpose of this study is to determine the causes of disruption of electricity, and produce a new master installation design to improve the system.

Based on the results of the analysis, it was found that the importance of channel separation between loads to the Dean building with the Departement of Architecture building with cable capacity for the Dean building of NYY 4 x $95 \mathrm{~mm} 2$ and the safety of the NFb 200 Ampere mains. For cables to the building load, the Departement of Architecture installed a new main cable with NYY 4 x $50 \mathrm{~mm} 2$ cable size and NFb 150A main safety. It is necessary to replace the main NFb safety at the MDP parent panel which supplies the load to the Departement of Mechanical Engineering building from 160 Ampere to 200 Ampere. The entire phase in each panel does not meet the IEEE 519 - 2014 standard, so it is very important to install a filter. Ground resistance values on all panels vary above the standard with a value of 12 to $62 \mathrm{ohms}$. So it needs to be made a new grounding. When using a plate grounding system, the number of plates that need to be planted is 25 sheets with a size of $2 \mathrm{~m} \times 1 \mathrm{~m}$ with a planting depth of $2 \mathrm{~m}$. Whereas when using a grid type earth system, a grid with a size of 3 meters $\mathrm{x} 3$ meters is needed with a total grid length of 2976 meters and a depth of 3 meters.
\end{abstract}

Index Terms - Main electrical installation design, electrical power quality

Based on these problems, research on the existing main installation in the electrical system at the Faculty of

\section{INTRODUCTION}

Electrical systems that servethe Dean of electricity load, the electricity load of the Departement of Architecture, Departement of Mechanical Engineering, Departement of Electrical Engineering, Departement of Information Technology, external lighting facilities supplied by transformers with a capacity of 200 KVA. Lately the quality electrical system has begun to decline with frequent interruptions such as the breakdown of electricity to the load, unbalanced load, THD current exceeds the standard, the fuse on the incoming to the parent panel and the fuse on the main panel is often burned, the grounding system resistance value exceeds the standard equipment value, cable temperature exceeds the standard, voltage rises to 500 volts. The purpose of this study is to determine the causes of disruption of electricity, and produce a new master installation design to improve the system.
Engineering, Udayana University Bukit Jimbaran is conducted to avoid the cut off of electricity to the loads and also to improve the quality of electrical power.

\section{REVIEW OF LITERATURES}

\subsection{State of the Art}

In the study "Analysis of the Effect of Load and Harmonics Imbalance on Imposition in Neutral Wire and Transformer Power Loss". The results of the analysis showed that the higher the level of load imbalance and harmonic distortion, the higher the level of loading is treated neutral which results in increased losses of transformer [1].

In the research "Analysis of Grounding System As Building Equipment Security Udayana University Denpasar" obtained results that in sandy clay soil, for earthing resistance value $\leq 3 \mathrm{ohms}$, earthing type 1 (one) rod requires a minimum depth of 14 meters, type $2 \operatorname{rod~s}<$ $\mathrm{L}$ depth of at least 8 meters distance between rods 2 
meters, earthing type 2 rod $S>L$ minimum depth of 6 meters with spacing between rods 8 meters, type of earthing plate with $3 \times 1$ meter plate length 2 meters depth and grid type with a total length of 504 electrodes 2.5 meter depth meter [2].

The results of the study "The Effect of Age on Several Bentonite Additive Substances Against Grounding Resistance Value", obtained the volume of bentonite has a significant effect on the resistance value of the rod to a certain volume and is very suitable to be given to rocky soil (hard soil) [3].

Research "Difference in the addition of salt with Bentonite to the value of grounding resistance" shows that there is a difference between salt and bentonite to reduce the value of soil resistance, so that the resistance value of soil type filled with bentonite is smaller and causes the value of soil resistance to be smaller and suitable for on rocky soil [4].

In the study "Damping Harmonics Distortion Using Active Filters with PID Control at the Faculty of Engineering, Udayana University Bukit Jimbaran" stated that the current harmonic distortion (THDi) on the Bukit Jimbaran campus exceeds the IEEE 519 - 2014 standard of> $8 \%$ causing poor power quality [5].

\subsection{Power Installation}

The equipment used in the power installation are:

a. Safety

b. Delivery

c. Contacts

d. Pushbutton

e. Contactor

f. Panel

The safety used in an electrical system is [6]:

1. Safety of Feces (Fuse)

2. Mini Circuit Breaker (MCB)

3. Molded Case Circuit Breaker (MCCB)

4. No Fuse Breaker (NFB)

5. Thermal Overlay Relay (TOR)

The size of the cross sectional area and type of conveyor installed in an lighting installation or power installation is determined based on [7]:

1. Current Flow Capability (KHA) of conductors.

2. The voltage drop is allowed.

3. Neighborhood Temperature and Environmental

Properties.

4. Transmission Mechanical Power.

5. Possible expansion.

\subsection{Grounding System}

The grounding system is a circuit network starting from the grounding electrode pole, connecting to the earth terminal which serves to channel more current to the earth, so that the equipment can be protected from the influence of lightning and other foreign stresses [6], [8], [9 ]:

Plate electrodes are electrodes of metal plate material (intact or perforated) or from gauze wire mounted perpendicular to the ground [10].

\subsection{Harmonics}

Harmonics arises due to the operation of non-linear electricity loads. The height of harmonics results in poor power quality [12], [13], [14]: Two criteria of harmonics are current harmonic distortion (THDI) and harmonic harmonics (THDV).

\subsection{Types of Problems of Electric Power Quality}

The types of problems in the quality of electrical power are like transient symptoms, namely the symptoms of variable changes (voltage, current and others) that occur during the transition from a state of soft operation (steady state) to another state [12].

\section{RESEARCH METHOD}

\subsection{Research Location}

The study was conducted at the Faculty of Engineering of Udayana Hill University in Jimbaran and the Laboratory of Electrical Installation.

3.2 Research Steps

1. Collection of technical data for existing master installations.

2. Collection of existing load data

3. Measurement of earthing resistance on the transformer, and around the entire panel.

4. Measurement of soil resistance in the location of the entire panel.

5. Collecting THDi and THDv data.

6. Capacity analysis: safety, main conductor, earthing analysis and THD.

7. Main installation design

3.3 Data Analysis

1. Analysis of safety capacity, main carrying capacity.

2. Analysis of earthing systems and analysis of THDi and THDv.

\section{RESUlts AND DisCUSSION}

4.1 Electrical System at the Faculty of Engineering, Udayana University Bukit Jimbaran

Electrical systems that serve electricity loads: Dean, Department of Architecture, Department of Mechanical Engineering, Department of Electrical Engineering, Department of Information Technology, external lighting supplied by transformers with a capacity of $200 \mathrm{KVA}$.

\subsection{Electrical System Analysis}

The entire load is supplied from a $200 \mathrm{kVA}$ transformer along with a panel with a NT Fuse 355 Ampere main safeguard, forwarded to a Main Distribution Panel (MDP) main panel that is attached to the mother's safety at 350 Ampere MDP NFb. While the load in each Study Program has a DP (Distribution Panel) and SDP (Sub Distribution Panel) as in the diagram in line figure 3. 
TABLE I

RESULTS OF PEAK LOAD CAPASITY MEASUREMENT IN EACH LOAD CENTER

\begin{tabular}{|l|l|l|}
\hline No & \multicolumn{1}{|c|}{ Load Location } & \multicolumn{1}{|c|}{$\begin{array}{c}\text { Load Capacity } \\
(\mathrm{kW})\end{array}$} \\
\hline 1 & $\begin{array}{l}\text { Departement of Architecture and } \\
\text { Dean Building }\end{array}$ & 50,6 \\
\hline 2 & $\begin{array}{l}\text { Departement of Mechanical } \\
\text { Engineering }\end{array}$ & 36,25 \\
\hline 3 & $\begin{array}{l}\text { Department of Electrical } \\
\text { Engineering }\end{array}$ & 27 \\
\hline 4 & $\begin{array}{l}\text { Department of Information } \\
\text { Technology }\end{array}$ & 35 \\
\hline 5 & Undagi Graha & 3,4 \\
\hline & Total & 144,25 \\
\hline
\end{tabular}

\subsubsection{Department of Electrical Engineering Building} TABLE II

RESUlts OF MEASUREMENT ON THE Distribution PANEL OF THE ELECTRICAL ENGINEERING BUILDING

\begin{tabular}{|c|c|c|c|}
\hline PHASA & COS PHI & VOLTAGE $(\mathrm{V})$ & CURRENT $(\mathrm{A})$ \\
\hline \multirow{2}{*}{$\mathrm{R}$} & \multirow{3}{*}{0.94} & 222 & 102 \\
\cline { 4 - 4 } $\mathrm{S}$ & & 228.4 & 60 \\
\cline { 3 - 4 } $\mathrm{T}$ & & 225.6 & 77 \\
\hline
\end{tabular}

Total Power is $27 \mathrm{KW}$. Using NYY Cable as the main cable with a size of $4 \times 95 \mathrm{~mm} 2$.

\subsubsection{Departement of Mechanical Engineering Departement Building}

TABLE III

MEASUREMENT RESULT ON THE DISTRIBUTION PANEL OF MECHANICAL ENGINEERING

\begin{tabular}{|c|c|c|c|}
\hline PHASA & COS PHI & VOLTAGE $(\mathrm{V})$ & CURRENT $(\mathrm{A})$ \\
\hline \multirow{2}{*}{$\mathrm{R}$} & \multirow{3}{*}{0.91} & 220 & 142.5 \\
\cline { 1 - 2 } \cline { 3 - 4 } $\mathrm{S}$ & 230 & 67.5 \\
\cline { 1 - 1 } $\mathrm{n}$ & & 229 & 48 \\
\hline
\end{tabular}

Total Power is $36.25 \mathrm{KW}$. Using NYY cable as the main cable with a size of $4 \times 95 \mathrm{~mm} 2$.

\subsubsection{Dean and Department of Architecture Building}

TABLE IV

MEASUREMENT RESULT ON THE DISTRIBUTION PANELS OF 1st AND 2nd FLOOR BUILDINGS

\begin{tabular}{|c|c|c|c|}
\hline PHASA & COS PHI & VOLTAGE (V) & CURRENT (A) \\
\hline $\mathrm{R}$ & 0.99 & 194.1 & 45 \\
\hline $\mathrm{S}$ & 0.99 & 217 & 37.2 \\
\hline $\mathrm{T}$ & 0.99 & 215.9 & 22 \\
\hline
\end{tabular}

TABLE V

MEASUREMENT RESULT ON THE 3rd FLOOR DISTRIBUTION PANEL OF THE DEAN BUILDING

\begin{tabular}{|c|c|c|c|}
\hline PHASA & COS PHI & VoltaGe (V) & CURRENT (A) \\
\hline $\mathrm{R}$ & 0.95 & 193.4 & 23.24 \\
\hline $\mathrm{S}$ & 0.92 & 219.4 & 15.39 \\
\hline $\mathrm{T}$ & 0.79 & 212.1 & 13.05 \\
\hline
\end{tabular}

TABLE VI

MEASUREMENT RESULT ON THE DISTRIBUTION PANEL OF THE DEPARTEMENT OF ARCHITECTURE BUILDING

\begin{tabular}{|c|c|c|c|}
\hline PHASA & COS PHI & VOLTAGE (V) & CURRENT (A) \\
\hline \multirow{2}{*}{$\mathrm{R}$} & \multirow{3}{*}{0.99} & 220 & 53,8 \\
\cline { 1 - 2 } \cline { 3 - 4 } $\mathrm{S}$ & & 220 & 29 \\
\cline { 3 - 4 } $\mathrm{T}$ & & 229 & 29 \\
\hline
\end{tabular}

The total power in the Department of Architecture building is $21.6 \mathrm{~kW}$.

The buildings were supplied with one main cable using NYY Cable with a size of 4 x $95 \mathrm{~mm} 2$.

\subsubsection{Department of Information Technology Building TABLE VII}

MEASUREMENT RESULT ON THE DISTRIBUTION PANEL OF THE DEPARTEMENT OF INFORMATION TECHNOLOGY BUILDING

\begin{tabular}{|c|c|c|c|}
\hline PHASA & COS PHI & VOLTAGE (V) & CURRENT (A) \\
\hline \multirow{2}{*}{$\mathrm{R}$} & \multirow{3}{*}{0.98} & 221 & 95 \\
\cline { 1 - 2 } $\mathrm{S}$ & & 227 & 57,5 \\
\cline { 4 - 4 } $\mathrm{nnyy}$ & & 224.5 & 84 \\
\hline
\end{tabular}

Total power is $35 \mathrm{KW}$. Using NYY cable as the main cable with a size of $4 \times 95 \mathrm{~mm} 2$.

\subsubsection{Undagi Graha Building} TABLE VIII

MEASUREMENT RESULT ON THE DISTRIBUTION PANEL OF THE UNDAGI GRAHA BUILDING

\begin{tabular}{|c|c|c|c|}
\hline PHASA & COS PHI & TEGANGAN (V) & ARUS (A) \\
\hline \multirow{2}{*}{$\mathrm{R}$} & \multirow{3}{*}{0.69} & 222.5 & 17.5 \\
\cline { 1 - 3 } $\mathrm{S}$ & & 228.5 & 10.8 \\
\cline { 3 - 4 } $\mathrm{n}$ & & 229.5 & 14.2 \\
\hline
\end{tabular}

Total power of $3.4 \mathrm{KW}$ Using NYY cable as the main cable with a size of $4 \times 95 \mathrm{~mm} 2$.

Based on the measurement results of loading data at each phase is not balanced, this will affect the emergence of currents in neutral phases that should not have a current flowing and affect harmonics (THD current or THD voltage that does not meet the standards) so that it can reduce power quality. In addition, the existence of a number of buildings that use 1 panel for 2 buildings will affect the reliability of the two buildings. Then the redesign (re-design) of the system is made. Main installation from existing data to new planning data.

\subsection{Analysis of Electrical Installation Planning}

4.3.1 Planning Analysis of the main Dean building installation

From Existing Data it is known that the Architect and Dean Building is still combined with one main cable channel NYY $=4 \times 95 \mathrm{~mm} 2$ using one distribution panel with the main safety NFB 200 Ampere. To increase reliability and facilitate maintenance, it is necessary to plan a separate master installation between the burden of the Dean building and the building load of the Architecture Study Program. So it is necessary to analyze several parameters:

For the Dean building is known based on measurement data: 
$\mathrm{P}: 29 \mathrm{~kW}=29000 \mathrm{Watt}$

$\operatorname{Cos} \varphi: 0,99$

$\mathrm{V}: 220$ volt

$\mathrm{I}=\frac{29000}{220.0,99}=133,15 \mathrm{~A}$

The total power of 133.15 A, the type of cable used should be NYY 4x70 mm2 with the ability to conduct current of 228 Ampere in order to anticipate the development of the load going forward with the number of equipment that uses electric power supply, because currently the cable operated is also intended to load in the Department of Architecture building, the cable can still be used to serve the Dean building's burden, so it only needs to install one cable to service the building load of the Department of Architecture. The NFB mother body uses 160 Ampere.

4.3.2 Planning Analysis of the main building of the Architectural Departement building

Where based on measurement data:

$\mathrm{P}: 21,6 \mathrm{~kW}=21600$ watt

$\operatorname{Cos} \varphi: 0,98$

$\mathrm{V}: 220$ volt

$\mathrm{I}=\frac{21600}{220.0,98}=101,85 \mathrm{~A}$

The total power is $100,185 \mathrm{~A}$, the type of cable used is NYY 4 x 50 mm2 with the Current Carrying Ability (KHA) of 185 Amper. The cable used to service this load joins the load of the Dean building, so there needs to be an addition of a new cable channel with that size, NYY 4 x $50 \mathrm{~mm} 2$. The parent safety in the form of NPB uses a size of 150 Ampere.

4.3.3 Planning Analysis of the main installation of the building of Mechanical Engineering Departement

Based on measurement data:

$\mathrm{P}: 36,25 \mathrm{~kW}=36250$ watt

$\operatorname{Cos} \varphi: 0,91$

$\mathrm{V}: 220$ volt

$\mathrm{I}=\frac{36250}{220.0,91}=181,06 \mathrm{~A}$

Total load of 181.06 Ampere, preferably using a 4 x 95 mm2 NYY cable type as currently available with cable conductivity capability of 272 amperes. For safety can use NFB 200 Ampere. However, currently using NFb 160 Amper it is necessary to have a change if at a maximum load.

4.3.4 Installation planning analysis Main building of Electrical Engineering Departement

Based on measurement data:

$\mathrm{P}: 27 \mathrm{~kW}=27000 \mathrm{watt}$

$\operatorname{Cos} \varphi: 0,94$

$\mathrm{V}: 220$ volt

$\mathrm{I}=\frac{27000}{220.0,94}=130,5 \mathrm{~A}$

Total load of 130.5 Ampere, can use NYY 4 x $70 \mathrm{~mm} 2$ cable with conductivity of Current (KHA) of 228 A. The current conductor and NYY4 x $95 \mathrm{~mm} 2$ cable can still be used. Mains can use 160 Ampere NFB. Likewise, the NFb 200 Amper main safety can still be used. However, if there is a change, NFb 160 Ampere can be used.

\subsubsection{Installation planning analysis Main building of Information Technology}

Based on measurement data:

$\mathrm{P}: 35 \mathrm{~kW}=35000$ watt

$\operatorname{Cos} \varphi: 0,98$

$\mathrm{V}: 220$ volt

$\mathrm{I}=\frac{35000}{220.0,98}=162,33 \mathrm{~A}$

The total load is 162.33 Ampere, the type of cable used is NYY 4x70 mm2 with $\mathrm{NFb} 200$ Amper safety with the ability of Intensity Flow of 228 Ampere. However, with the imminent addition of Lift, we recommend that you keep using the existing $4 \times 95 \mathrm{~mm} 2 \mathrm{NYY}$ cable, but the capacity of the lifter must adjust to the size of the cable, only the $\mathrm{NFb}$ master safety adjusts, but still must be below the cable KHA.

\subsubsection{Installation planning analysis of the Undagi Graha building}

Based on measurement data:

$\mathrm{P}: 3,4 \mathrm{~kW}=3400$ watt

$\operatorname{Cos} \varphi: 0,69$

$\mathrm{V}: 220$

$\mathrm{I}=\frac{3400}{220.0,69}=23,39 \mathrm{~A}$

Total load is 23.39 Amper, Cable used is NYY 4 x $10 \mathrm{~mm} 2$ and safety of NFb 60 Ampere. However, the Undagi Graha building in the future planning will be used as a second floor building and will be planned for additional lecture rooms and others, then the existing NYY 4x95 mm2 cable and NFb 200 Amper main safety do not need to be changed. Based on the results of special calculations in the load group, cable size and safety capacity above, it can be concluded that to maintain the quality and reliability of the system there are several things to note are:

1. The importance of separating the channel between the load to the Dean building with the Architecture Study Program building with cable capacity for the $4 \times 95$ $\mathrm{mm} 2$ Dean of NYY building and the main safety of the $\mathrm{NFb} 200$ Amper can be used by the existing cable and safety guard. However, for the cable to the building load, the Architecture Study Program installed a new main cable channel with NYY 4 x $50 \mathrm{~mm} 2$ cable size with the conductivity of Current (KHA) of 185 Amper and NFb 150 Amper.

2. It is necessary to have a NFb main safety switch on the MDP parent panel that supplies the load to the Mechanical Engineering Study Program building from 160 Ampere to 200 Ampere. 


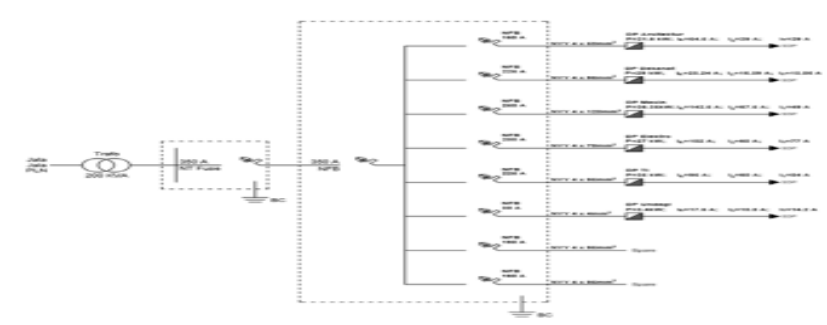

Figure I. Main Installation Segment Diagram from MDP to DP

\subsubsection{Harmonics Analysis THD I (current) and THD V (voltage)}

Based on the analysis, the current THD value to the whole phase has a THD> of the IEEE 519 - 2014 standard (> 8\%). It is very important to install a filter to reduce the current THD.

While the THD value of the voltage still meets the permitted standard $(<5 \%)$

\subsubsection{Grounding System}

Based on the results of the analysis of the two grounding systems namely the plate and grid system to get an grounding resistance value of $<1 \mathrm{ohm}$ it can be recommended that, when using a plate grounding system, the number of plates that need to be planted is 25 sheets with a size of $2 \times 1$ meter with a depth of planting 2 meter. Whereas when using a grid type earth system, a grid with a size of 3 meters $\times 3$ meters is needed with a total grid conductor length of 2976 meters and a 3 meter installation depth.

\section{CONCLUSION AND RECOMMENDATION}

5.1 Conclusion

1. Separation of the channel between the load to the Dean building and the Departement of Architecture building with cable capacity for the $4 \times 95 \mathrm{~mm} 2$ Dean of NYY building and the NFb 200 Amper main safety so that the existing cable and safety guard can still be used. However, for the cable to the building load, the Departement of Architecture installed a new master cable with NYY 4 x $50 \quad \mathrm{~mm} 2$ cable size with conductivity of conductors (KHA) of 185 Amper and $\mathrm{NFb} 150$ Amper main safety.

2. It is necessary to have a NFb main safety switch on the MDP parent panel that supplies the load to the Departement of Mechanical Engineering from 160 Ampere to 200 Ampere.

3. Although the cable and safety used in the load in the Information Technology Study Program building and
Undagi Graha building are still relatively far above the capacity according to the analysis, but the two loads on the building will be planned to increase the load so the channel is still operated.

4. Ground resistance to all panels (MDP, DP and SDP) has a very large value (>1 ohm), so it is very important to make a new grounding system.

5. Based on the THD analysis, the entire phase in each panel as in table 9 does not meet the IEEE 519 - 2014 standard, so it is very important to install a filter to reduce the THD current to meet IEEE 519 - 2014 standards.

6. To get the earthing resistance value $<1 \mathrm{ohm}$ can be used plate type or grid type. When using a plate earthing system, the number of plates that need to be planted is 25 sheets with a size of 2 meters $\mathrm{x} 1$ meter with a depth of 2 meters. Where as when using a grid type grounding system, a grid with a size of 3 meters $x$ 3 meters is needed with a total grid length of 2976 meters and a 3 meter installation depth.

\subsection{Recommendation}

Based on the results of the study can be suggested to do research with the treatment of grouping non-linear loads, namely groups of lights, groups of air conditioning systems and groups of other equipment such as: LCD, computers and others to find out the equipment that most influences the increase in THD. As well as installation research in each group in order to be able to make the overall installation design used for making the final image as a reference in maintenance.

\section{REFERENCES}

[1] Garniwa, dkk . 2013. Analisis Pengaruh Ketidakseimbangan Beban dan Harmonisa Terhadap Pembebanan di Kawat Netral dan Rugi Daya Transformator.

[2] Janardana, IGN. 2017. Analysis Grounding System As Building Equipment Security Udayana University Denpasar" IRCS Journal.

[3] Janardana, IGN. 2005. Pengaruh Umur Pada Beberapa Volume Zat Aditif Bentonit Terhadap Nilai Tahanan Pentanahan. Jurnal Teknologi Energi, Voluma 2

[4] Janardana, IGN. 2005. Perbedaan penambahan Garam dengan Bentonit Terhadap Nilai Tahanan Pentanahan. Jurnal Teknologi Energi, Volume 2.

[5] Suartika, M. Peredaman Distorsi Harmonisa Menggunakan Filter Aktif Dengan Kontrol PID Di Fakultas Teknik Universitas Udayana Kampus Bukit Jimbaran. PS. Teknik Elektro Unud. 
[6] Hutauruk.TS.1987. Pengetanahan Netral dengan sistem Tenaga dan Pengetanahan Peralatam. Jakarta Erlangga.

[7] PUIL 2011. Persyaratan Umum Instalasi Listrik.

[8] Mahendra, IGMO. 2004. Study Kasus Kegagalan Proteksi Dari Bahaya Petir DI Hotel Sanur Beach Bali. Tugas Akhir. Denpasar: Teknik Elektro.

[9] Sutikno, dkk. 1997. External \& Internal Grounding. Bandung :DIVLAT PT. Telkom.

[10]IEEE Recommended Practices and Requirements for Harmonic Control in Electric Power Systems. IEEE Standard 519-2014.

[11] Janardana, IGN. 2005. Pengaruh Umur Pada Beberapa Volume Zat Aditif Bentonit Terhadap Nilai Tahanan Pentanahan. Jurnal Teknologi Energi, Voluma 2

[12]Dugan, RC., dkk. 2012. Electrical Power Systems Quality, Third Edition. McGraw Hill Professional.

[13] Susiono. 1999. Penentuan Lokasi Lokasi Filter Harmonik Optimum Pada Sistem Distribusi Daya Listrik.Surabaya : Program Studi Teknik Elektro Institut Teknologi Sepuluh Nopember. 